\title{
Can apparent diffusion coefficient (ADC) distinguish breast cancer from benign breast findings? A meta-analysis based on 13847 lesions
}

\author{
Alexey Surov ${ }^{1,2^{*}+}\left(\mathbb{D}\right.$, Hans Jonas Meyer ${ }^{1+}$ and Andreas Wienke ${ }^{3+}$
}

\begin{abstract}
Background: The purpose of the present meta-analysis was to provide evident data about use of Apparent Diffusion Coefficient (ADC) values for distinguishing malignant and benign breast lesions.

Methods: MEDLINE library and SCOPUS database were screened for associations between ADC and malignancy/ benignancy of breast lesions up to December 2018. Overall, 123 items were identified. The following data were extracted from the literature: authors, year of publication, study design, number of patients/lesions, lesion type, mean value and standard deviation of ADC, measure method, $b$ values, and Tesla strength.

The methodological quality of the 123 studies was checked according to the QUADAS-2 instrument. The metaanalysis was undertaken by using RevMan 5.3 software. DerSimonian and Laird random-effects models with inversevariance weights were used without any further correction to account for the heterogeneity between the studies. Mean ADC values including 95\% confidence intervals were calculated separately for benign and malign lesions.

Results: The acquired 123 studies comprised 13,847 breast lesions. Malignant lesions were diagnosed in 10,622 cases (76.7\%) and benign lesions in 3225 cases (23.3\%). The mean ADC value of the malignant lesions was $1.03 \times$ $10^{-3} \mathrm{~mm}^{2} / \mathrm{s}$ and the mean value of the benign lesions was $1.5 \times 10^{-3} \mathrm{~mm}^{2} / \mathrm{s}$. The calculated ADC values of benign lesions were over the value of $1.00 \times 10^{-3} \mathrm{~mm}^{2} / \mathrm{s}$. This result was independent on Tesla strength, choice of $b$ values, and measure methods (whole lesion measure vs estimation of ADC in a single area).

Conclusion: An ADC threshold of $1.00 \times 10^{-3} \mathrm{~mm}^{2} / \mathrm{s}$ can be recommended for distinguishing breast cancers from benign lesions.
\end{abstract}

Keywords: Breast cancer, ADC, MRI

\section{Background}

Magnetic resonance imaging (MRI) plays an essential diagnostic role in breast cancer (BC) [1, 2]. MRI has been established as the most sensitive diagnostic modality in breast imaging [1-3]. Furthermore, MRI can also predict response to treatment in $\mathrm{BC}$ [4]. However, it has

\footnotetext{
* Correspondence: Alexey.Surov@medizin.uni-leipzig.de

${ }^{\dagger}$ Alexey Surov, Hans Jonas Meyer and Andreas Wienke contributed equally to this work.

${ }^{1}$ Department of Diagnostic and Interventional Radiology, University of Leipzig, Liebigstr. 20, 04103 Leipzig, Germany

${ }^{2}$ Department of Diagnostic and Interventional Radiology, Ulm University

Medical Center, Albert-Einstein-Allee 23, 89081 Ulm, Germany

Full list of author information is available at the end of the article
}

a high sensitivity but low specificity [5]. Therefore, MRI can often not distinguish malignant and benign breast lesions. Numerous studies reported that diffusionweighted imaging (DWI) has a great diagnostic potential and can better characterize breast lesions than conventional MRI [6-8]. DWI is a magnetic resonance imaging (MRI) technique based on measure of water diffusion in tissues [9]. Furthermore, restriction of water diffusion can be quantified by apparent diffusion coefficient (ADC) $[9,10]$. It has been shown that malignant tumors have lower values in comparison to benign lesions [7]. In addition, according to the literature, ADC is associated with several histopathological features, such as cell

(c) The Author(s). 2019 Open Access This article is distributed under the terms of the Creative Commons Attribution 4.0 International License (http://creativecommons.org/licenses/by/4.0/), which permits unrestricted use, distribution, and reproduction in any medium, provided you give appropriate credit to the original author(s) and the source, provide a link to the Creative Commons license, and indicate if changes were made. The Creative Commons Public Domain Dedication waiver (http://creativecommons.org/publicdomain/zero/1.0/) applies to the data made available in this article, unless otherwise stated. 
count and expression of proliferation markers, in different tumors [11, 12].

However, use of ADC for discrimination $\mathrm{BC}$ and benign breast lesions is difficult because of several problems. Firstly, most reports regarding ADC in several breast cancers and benign breast lesions investigated relatively small patients/lesions samples. Secondly, the studies had different proportions of malignant and benign lesions. Thirdly and most importantly, the reported ADC threshold values and as well specificity, sensitivity, and accuracy values ranged significantly between studies. For example, in the study of Aribal et al., 129 patients with 138 lesions (benign $n=$ 63; malignant $n=75$ ) were enrolled [13]. The authors reported the optimal ADC cut-off as $1.118 \times 10^{-3} \mathrm{~mm} 2 / \mathrm{s}$ with sensitivity and specificity 90.67 , and $84.13 \%$ respectively [13]. In a study by Arponen et al., which investigated 112 patients (23 benign and 114 malignant lesions), the ADC threshold was $0.87 \times 10^{-3} \mathrm{~mm}^{2} / \mathrm{s}$ with $95.7 \%$ sensitivity, $89.5 \%$ specificity and overall accuracy of $89.8 \%$ [14].
Cakir et al. reported in their study with 52 women and 55 breast lesions (30 malignant, 25 benign) an optimal ADC threshold as $\leq 1.23 \times 10^{-3} \mathrm{~mm}^{2} / \mathrm{s}$ (sensitivity $=92.85 \%$, specificity $=54.54 \%$, positive predictive value $=72.22 \%$, negative predictive value $=85.71 \%$, and accuracy $=0.82$ ) [15] Finally, different MRI scanners, Tesla strengths and b values were used in the reported studies, which are known to have a strong influence in ADC measurements. These facts question the possibility to use the reported ADC thresholds in clinical practice.

To overcome these mentioned shortcomings, the purpose of the present meta-analysis was to provide evident data about use of ADC values for distinguishing malignant and benign breast lesions.

\section{Methods}

Data acquisition and proving

Figure 1 shows the strategy of data acquisition. MEDLINE library and SCOPUS database were screened for associations between ADC and malignancy/benignancy

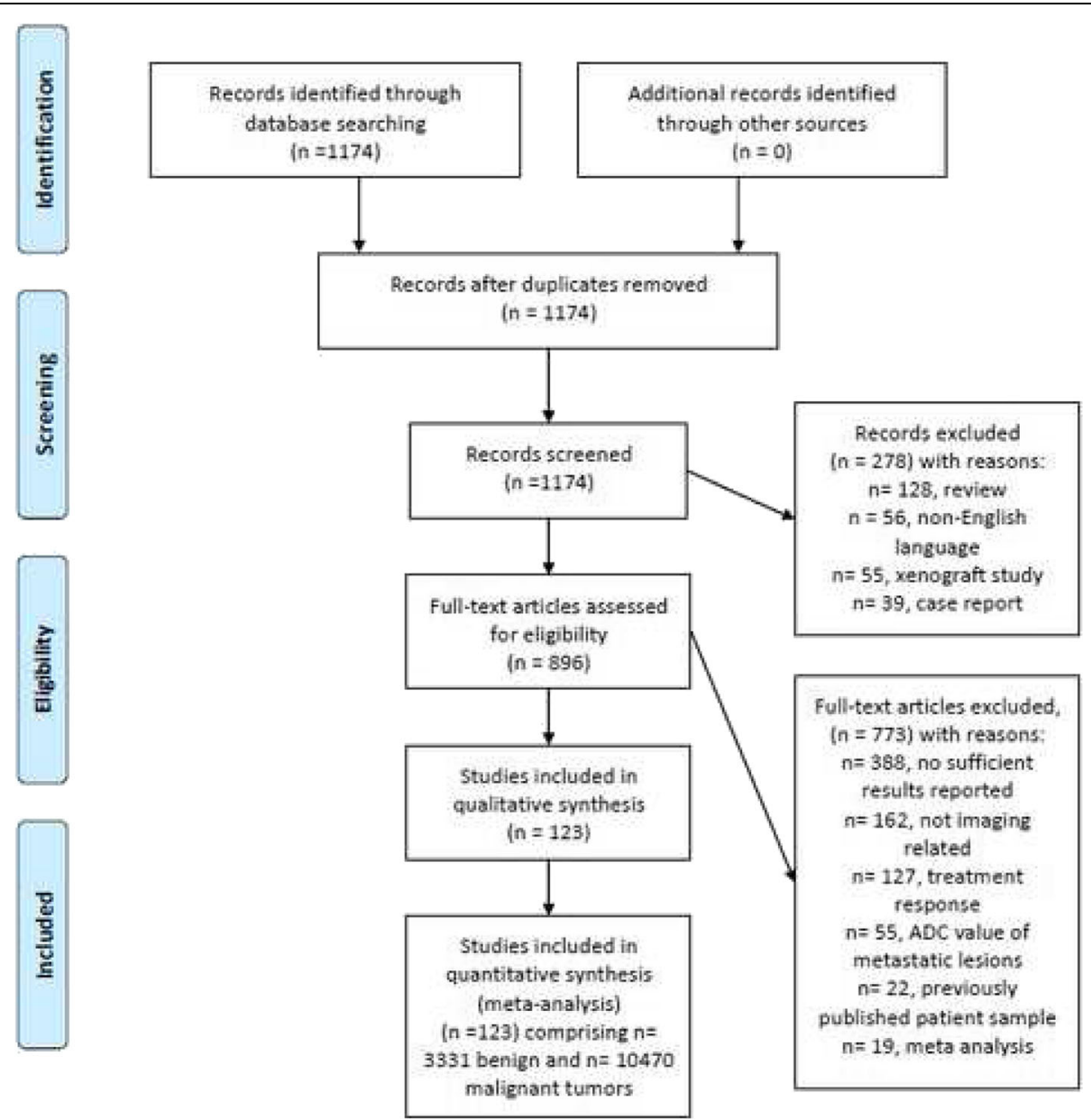

Fig. 1 PRISMA flow chart of the data acquisition 

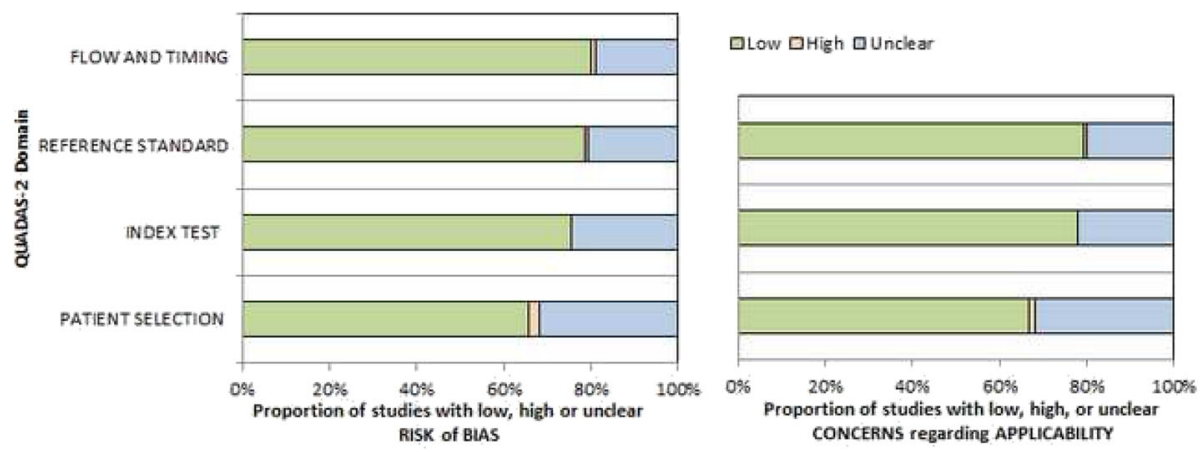

Fig. 2 QUADAS-2 quality assessment of the included studies

of breast lesions up to December 2018. The following search terms/combinations were as follows:

"DWI or diffusion weighted imaging or diffusionweighted imaging or ADC or apparent diffusion coefficient AND breast cancer OR breast carcinoma OR mammary cancer OR breast neoplasm OR breast tumor". Secondary references were also manually checked and recruited. The Preferred Reporting Items for Systematic Reviews and Meta-Analyses statement (PRISMA) was used for the research [16].

Overall, the primary search identified 1174 records. The abstracts of the items were checked. Inclusion criteria for this work were as follows:

- Data regarding ADC derived from diffusion weighted imaging (DWI);

- Available mean and standard deviation values of ADC;

- Original studies investigated humans;

- English language.
Overall, 127 items met the inclusion criteria. Other 1017 records were excluded from the analysis. Exclusion criteria were as follows:

- studies unrelated to the research subjects;

- studies with incomplete data;

- non-English language;

- duplicate publications;

- experimental animals and in vitro studies;

- review, meta-analysis and case report articles;

The following data were extracted from the literature: authors, year of publication, study design, number of patients/lesions, lesion type, mean value and standard deviation of ADC, and Tesla strength.

\section{Meta-analysis}

On the first step, the methodological quality of the 123 studies was checked according to the Quality Assessment of Diagnostic Studies (QUADAS-2) instrument

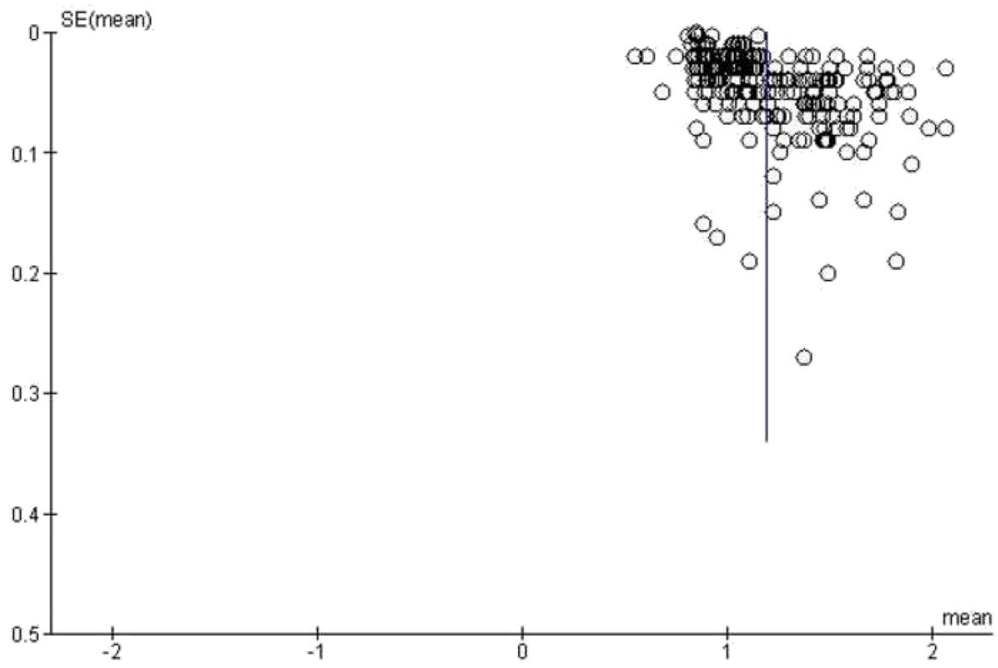

Fig. 3 Funnel plot of the publication bias 
Table 1 Studies inclujded into the meta-analysis

\begin{tabular}{|c|c|c|c|c|}
\hline Author, years [Ref.]. & $\begin{array}{l}\text { Malignant } \\
\text { lesions, } \mathrm{n}\end{array}$ & $\begin{array}{l}\text { benign } \\
\text { lesions, } \mathrm{n}\end{array}$ & $\begin{array}{l}\text { Study } \\
\text { design }\end{array}$ & $\begin{array}{l}\text { Tesla } \\
\text { strength }\end{array}$ \\
\hline Akin et al., 2016 [21] & 89 & 92 & retrospective & 3 \\
\hline An et al., 2017 [22] & 112 & 32 & prospective & 3 \\
\hline Arponen et al., 2015 [14] & 114 & 23 & retrospective & 3 \\
\hline Arponen et al., 2018 [23] & 25 & 7 & retrospective & 3 \\
\hline Baba et al., 2014 [24] & 70 & 13 & retrospective & 1.5 \\
\hline Baltzer et al., 2010 [25] & 54 & 27 & retrospective & 1.5 \\
\hline Belli et al., 2015 [26] & 289 & & retrospective & 1.5 \\
\hline Belli et al., 2010 [27] & 100 & 26 & retrospective & 1.5 \\
\hline Bickel et al., 2015 [28] & 176 & & retrospective & 3 \\
\hline Bogner et al., 2009 [29] & 24 & 17 & retrospective & 3 \\
\hline $\begin{array}{l}\text { Bokacheva et al., } \\
2014 \text { [30] }\end{array}$ & 26 & 14 & retrospective & 3 \\
\hline Çabuk et al., 2015 [31] & 22 & 41 & retrospective & 1.5 \\
\hline Cai et al., 2014 [32] & 149 & 85 & retrospective & 1.5 \\
\hline Caivano et al., 2015 [33] & 67 & 43 & retrospective & 3 \\
\hline Cakir et al., 2013 [15] & 30 & 25 & retrospective & 3 \\
\hline Chen et al., 2012 [34] & 39 & 18 & retrospective & 1.5 \\
\hline Chen et al., 2018 [35] & 72 & 44 & prospective & 3 \\
\hline Cheng et al., 2013 [36] & 128 & 60 & retrospective & 1.5 \\
\hline Cho et al., 2016 [37] & 50 & 12 & retrospective & 3 \\
\hline Cho et al., 2015 [38] & 38 & & retrospective & 3 \\
\hline Choi et al., 2017 [39] & 34 & & retrospective & $\begin{array}{l}3 \text { and } \\
1.5\end{array}$ \\
\hline Choi et al., 2018 [40] & 78 & & prospective & 3 \\
\hline Choi et al., 2012 [41] & 335 & & retrospective & 1.5 \\
\hline Choi et al., 2017 [42] & 221 & & retrospective & 3 \\
\hline Cipolla et al., 2014 [43] & 106 & & retrospective & 3 \\
\hline $\begin{array}{l}\text { Costantini et al., } \\
2012 \text { [44] }\end{array}$ & 225 & & retrospective & 1.5 \\
\hline $\begin{array}{l}\text { Costantini et al., } \\
2010 \text { [45] }\end{array}$ & 162 & & prospective & 1.5 \\
\hline $\begin{array}{l}\text { de Almeida et al., } \\
2017 \text { [46] }\end{array}$ & 44 & 37 & retrospective & 1.5 \\
\hline Durando et al., 2016 [47] & 126 & & retrospective & 3 \\
\hline $\begin{array}{l}\text { Eghtedari et al., } \\
2016 \text { [48] }\end{array}$ & 33 & 18 & retrospective & $\begin{array}{l}3 \text { and } \\
1.5\end{array}$ \\
\hline Ertas et al., 2016 [49] & 85 & 85 & retrospective & 3 \\
\hline Ertas et al., 2018 [50] & 85 & 88 & retrospective & 3 \\
\hline Fan et al., 2018 [51] & 126 & & retrospective & 3 \\
\hline Fan et al., 2018 [52] & 68 & 21 & retrospective & 3 \\
\hline Fan et al., 2017 [53] & 82 & & retrospective & 3 \\
\hline $\begin{array}{l}\text { Fanariotis et al., } \\
2018 \text { [54] }\end{array}$ & 59 & 41 & retrospective & 3 \\
\hline Fornasa et al., 2011 [55] & 35 & 43 & retrospective & 1.5 \\
\hline Gity et al., 2018 [56] & 50 & 48 & prospective & 1.5 \\
\hline Guatelli et al., 2017 [57] & 161 & 91 & retrospective & 1.5 \\
\hline
\end{tabular}

Table 1 Studies inclujded into the meta-analysis (Continued)

\begin{tabular}{|c|c|c|c|c|}
\hline Author, years [Ref.]. & $\begin{array}{l}\text { Malignant } \\
\text { lesions, } \mathrm{n}\end{array}$ & $\begin{array}{l}\text { benign } \\
\text { lesions, } \mathrm{n}\end{array}$ & $\begin{array}{l}\text { Study } \\
\text { design }\end{array}$ & $\begin{array}{l}\text { Tesla } \\
\text { strength }\end{array}$ \\
\hline Hering et al., 2016 [58] & 25 & 31 & retrospective & 1.5 \\
\hline Hirano et al., 2012 [59] & 48 & 27 & retrospective & 3 \\
\hline Horvat et al., 2018 [60] & 218 & 130 & retrospective & 3 \\
\hline Hu et al., 2018 [61] & 52 & 36 & retrospective & 3 \\
\hline Huang et al., 2018 [62] & 50 & 26 & prospective & 3 \\
\hline lima et al., 2011 [63] & 25 & & retrospective & 1.5 \\
\hline Imamura et al., 2010 [64] & 16 & 11 & retrospective & 1.5 \\
\hline Inoue et al., 2011 [65] & 91 & 15 & retrospective & 1.5 \\
\hline Janka et al., 2014 [66] & 59 & 20 & retrospective & 1.5 \\
\hline Jeh et al., 2011 [67] & 155 & & retrospective & $\begin{array}{l}3 \text { and } \\
1.5\end{array}$ \\
\hline Jiang et al., 2018 [68] & 171 & 104 & retrospective & 1.5 \\
\hline Jiang et al., 2014 [69] & 64 & & retrospective & 1.5 \\
\hline Jin et al., 2010 [70] & 40 & 20 & retrospective & 1.5 \\
\hline Kanao et al., 2018 [71] & 79 & 83 & retrospective & $\begin{array}{l}3 \text { and } \\
1.5\end{array}$ \\
\hline $\begin{array}{l}\text { Kawashima et al., } \\
2017 \text { [72] }\end{array}$ & 137 & & retrospective & 3 \\
\hline Ei Khouli et al., 2010 [73] & 101 & 33 & retrospective & 3 \\
\hline Kim et al., 2019 [74] & 93 & & retrospective & 3 \\
\hline Kim et al., 2018 [75] & 121 & 48 & retrospective & 3 \\
\hline Kim et al., 2018 [76] & 81 & & retrospective & 3 \\
\hline Kim et al., 2009 [77] & 60 & & retrospective & 1.5 \\
\hline Kitajima et al., 2018 [78] & 67 & & retrospective & 3 \\
\hline Kitajima et al., 2016 [79] & 216 & & retrospective & 3 \\
\hline $\begin{array}{l}\text { Köremezli Keskin et al., } \\
2018 \text { [80] }\end{array}$ & 59 & & retrospective & 1.5 \\
\hline Kul et al., 2018 [81] & 143 & 70 & retrospective & 1.5 \\
\hline Kuroki et al., 2004 [82] & 55 & 5 & retrospective & 1.5 \\
\hline Lee et al., 2016 [83] & 128 & & retrospective & 3 \\
\hline Lee et al., 2016 [84] & 52 & & retrospective & 3 \\
\hline Li et al., 2015 [85] & 55 & & retrospective & 3 \\
\hline Liu et al., 2017 [86] & 48 & 47 & retrospective & 3 \\
\hline Liu et al., 2015 [87] & 176 & & retrospective & 3 \\
\hline Lo et al., 2009 [88] & 20 & 11 & prospective & 3 \\
\hline $\begin{array}{l}\text { Matsubayashi et al., } \\
2010 \text { [89] }\end{array}$ & 26 & & retrospective & 1.5 \\
\hline Min et al., 2015 [90] & 29 & 20 & retrospective & 1.5 \\
\hline $\begin{array}{l}\text { Montemezzi et al., } \\
2018 \text { [91] }\end{array}$ & 453 & & prospective & 3 \\
\hline Mori et al., 2013 [92] & 51 & & retrospective & 3 \\
\hline Nakajo et al., 2010 [93] & 51 & & retrospective & 1.5 \\
\hline Nogueira et al., 2015 [94] & 28 & 30 & prospective & 3 \\
\hline Nogueira et al., 2014 [95] & 89 & 68 & prospective & 3 \\
\hline Ochi et al., 2013 [96] & 59 & 45 & retrospective & 1.5 \\
\hline Onishi et al., 2014 [97] & 17 & & retrospective & 3 and \\
\hline
\end{tabular}


Table 1 Studies inclujded into the meta-analysis (Continued)

\begin{tabular}{|c|c|c|c|c|}
\hline Author, years [Ref.]. & $\begin{array}{l}\text { Malignant } \\
\text { lesions, } \mathrm{n}\end{array}$ & $\begin{array}{l}\text { benign } \\
\text { lesions, } \mathrm{n}\end{array}$ & $\begin{array}{l}\text { Study } \\
\text { design }\end{array}$ & $\begin{array}{l}\text { Tesla } \\
\text { strength }\end{array}$ \\
\hline & & & & 1.5 \\
\hline Ouyang et al., 2014 [98] & 23 & 16 & retrospective & 3 \\
\hline Park et al., 2017 [99] & 201 & & retrospective & 3 \\
\hline Park et al., 2016 [100] & 71 & & prospective & 3 \\
\hline Park et al., 2007 [101] & 50 & & retrospective & 1.5 \\
\hline Park et al., 2015 [102] & 110 & & retrospective & 3 \\
\hline Parsian et al., 2012 [103] & & 175 & retrospective & 1.5 \\
\hline Parsian et al., 2016 [104] & & 26 & retrospective & 1.5 \\
\hline $\begin{array}{l}\text { Partridge et al., } \\
2018 \text { [105] }\end{array}$ & 242 & & prospective & $\begin{array}{l}3 \text { and } \\
1.5\end{array}$ \\
\hline $\begin{array}{l}\text { Partridge et al., } 2011 \\
\text { [106] }\end{array}$ & 27 & 73 & retrospective & 1.5 \\
\hline $\begin{array}{l}\text { Partridge et al., } 2010 \\
\text { [107] }\end{array}$ & 29 & 87 & retrospective & 1.5 \\
\hline $\begin{array}{l}\text { Partridge et al., } \\
2010 \text { [108] }\end{array}$ & 21 & 91 & retrospective & 1.5 \\
\hline Pereira et al., 2009 [109] & 26 & 26 & prospective & 1.5 \\
\hline Petralia et al., 2011 [110] & 28 & & prospective & 1.5 \\
\hline Rahbar et al., 2011 [111] & 74 & & retrospective & 1.5 \\
\hline Rahbar et al., 2012 [112] & 36 & & retrospective & 1.5 \\
\hline $\begin{array}{l}\text { Ramírez-Galván et al., } \\
2015 \text { [113] }\end{array}$ & 15 & 21 & prospective & 1.5 \\
\hline Razek et al., 2010 [114] & 66 & & prospective & 1.5 \\
\hline $\begin{array}{l}\text { Roknsharifi et al., } \\
2018 \text { [115] }\end{array}$ & 97 & 59 & retrospective & 1.5 \\
\hline $\begin{array}{l}\text { Rubesova et al., } \\
2006 \text { [116] }\end{array}$ & 65 & 25 & retrospective & 1.5 \\
\hline Sahin et al., 2013 [117] & 35 & 16 & retrospective & 1.5 \\
\hline Satake et al., 2011 [118] & 88 & 27 & retrospective & 3 \\
\hline Sharma et al., 2016 [119] & 259 & 67 & prospective & 1.5 \\
\hline Shen et al., 2018 [120] & 71 & & retrospective & 3 \\
\hline Song et al., 2019 [121] & 85 & & retrospective & 3 \\
\hline Song et al., 2017 [122] & 106 & 25 & prospective & 3 \\
\hline Sonmez et al., 2011 [123] & 25 & 20 & retrospective & 1.5 \\
\hline Spick et al., 2016 [124] & 31 & 24 & prospective & 3 \\
\hline Spick et al., 2016 [125] & 20 & 84 & retrospective & 1.5 \\
\hline Suo et al., 2019 [126] & 134 & & retrospective & 3 \\
\hline Tang et al., 2018 [127] & 54 & 32 & retrospective & 3 \\
\hline Teruel et al., 2016 [128] & 34 & 27 & prospective & 3 \\
\hline Teruel et al., 2016 [129] & 38 & 34 & prospective & 3 \\
\hline Thakur et al., 2018 [130] & 31 & & retrospective & 3 \\
\hline Wan et al., 2016 [131] & 74 & 21 & retrospective & 1.5 \\
\hline Wang et al., 2016 [132] & 31 & 20 & retrospective & 3 \\
\hline $\begin{array}{l}\text { Woodhams et al., } \\
2009 \text { [133] }\end{array}$ & 204 & 58 & prospective & 1.5 \\
\hline Xie et al., 2019 [134] & 134 & & retrospective & 3 \\
\hline
\end{tabular}

Table 1 Studies inclujded into the meta-analysis (Continued)

\begin{tabular}{lllll}
\hline Author, years [Ref.]. & $\begin{array}{l}\text { Malignant } \\
\text { lesions, n }\end{array}$ & $\begin{array}{l}\text { benign } \\
\text { lesions, n }\end{array}$ & $\begin{array}{l}\text { Study } \\
\text { design }\end{array}$ & $\begin{array}{l}\text { Tesla } \\
\text { strength }\end{array}$ \\
\hline $\begin{array}{l}\text { Yabuuchi et al., } \\
\text { 2006 [135] }\end{array}$ & 19 & retrospective & 1.5 \\
Yoo et al., 2014 [136] & 106 & 63 & retrospective & 1.5 \\
Youk et al., 2012 [137] & 271 & & retrospective & 3 and \\
& & & retrospective 3 \\
Zhang et al., 2019 [138] & 136 & 74 & retrospective 3 \\
Zhao et al., 2018 [139] & 25 & 23 & retrospective 3 \\
Zhao et al., 2018 [140] & 119 & 22 & retrospective 3 \\
Zhou et al., 2018 [141] & 33 & 39 &
\end{tabular}

[17] independently by two observers (A.S. and H.J.M.). The results of QUADAS-2 assessment are shown in Fig. 2. The quality of most studies showed an overall low risk of bias.

On the second step, the reported ADC values (mean and standard deviation) were acquired from the papers.

Thirdly, the meta-analysis was undertaken by using RevMan 5.3 [RevMan 2014. The Cochrane Collaboration Review Manager Version 5.3.]. Heterogeneity was calculated by means of the inconsistency index $\mathrm{I}^{2}[18,19]$. In a subgroup analysis, studies were stratified by tumor type. In addition, DerSimonian and Laird random-effects models with inverse-variance weights were used without any further correction [20] to account for the heterogeneity between the studies (Fig. 3). Mean ADC values including 95\% confidence intervals were calculated separately for benign and malign lesions.

\section{Results}

Of the included 123 studies, 101 (82.1\%) were retrospective and $22(17.9 \%)$ prospective (Table 1$)$. The studies represented almost all continents and originated from Asia $(n=77,62.6 \%)$, Europe $(n=23,18.7 \%)$, North America $(n=19,15.5 \%)$, South America $(n=3,2.4 \%)$, and Africa $(n=1,0.8 \%)$. Different $1.5 \mathrm{~T}$ scanners were used in $53(43.1 \%)$ studies, $3 \mathrm{~T}$ scanners in 63 reports (51.2\%), and in 7 studies (5.7\%) both 1.5 and $3 \mathrm{~T}$ scanners were used. Overall, 68 studies $(55.3 \%)$ were performed/reported in the years 2015-2018, 46 studies (37.4\%) in the years 2010-2014, and 9 studies (7.3\%) in the years 2000 2009.

The acquired 123 studies comprised 13,847 breast lesions. Malignant lesions were diagnosed in 10,622 cases (76.7\%) and benign lesions in 3225 cases (23.3\%). The mean ADC value of the malignant lesions was $1.03 \times$ $10^{-3} \mathrm{~mm}^{2} / \mathrm{s}$ and the mean value of the benign lesions was $1.5 \times 10^{-3} \mathrm{~mm}^{2} / \mathrm{s}$ (Figs. 4 and 5). Figure 6 shows the distribution of ADC values in malignant and benign lesions. The ADC values of the two groups overlapped 
Mean

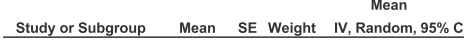

\begin{tabular}{lllll}
\hline Akin 2016a & 1.41 & 0.02 & $1.3 \%$ & $1.41[1.37,1.45$ \\
An 2017 & 1.14 & 0.04 & $1.3 \%$ & $1.14[1.06,1.22$
\end{tabular}

$\begin{array}{lrrrr}\text { An 2017 } & 1.14 & 0.04 & 1.3 \% & 1.14[1.06,1.22] \\ \text { Arponen 2015a } & 1.1 & 0.05 & 1.2 \% & 1.10[1.00,1.20]\end{array}$

$\begin{array}{lllll}\text { Arponen 2018 } & 1.1 & 0.05 & 1.2 \% & 1.10[1.00,1.20] \\ & 1.48 & 0.09 & 1.1 \% & 1.48[1.30,1.66]\end{array}$

$\begin{array}{lllll}\text { Baba 2014a } & 1.37 & 0.09 & 1.1 \% & 1.37[1.19,1.55]\end{array}$

$\begin{array}{lllll}\text { Baltzer } 2010 & 1.53 & 0.08 & 1.1 \% & 1.53[1.37,1.69]\end{array}$

Belli $2010 \quad 1.66 \quad 0.14 \quad 0.9 \% \quad 1.66[1.39,1.93]$

$\begin{array}{lrrrrr}\text { Bogner 2009 } & 1.58 & 0.07 & 1.2 \% & 1.58[1.44,1.72] \\ \text { Bokacheva 2014 } & 1.6 & 0.08 & 1.1 \% & 1.60[1.44,1.76]\end{array}$

$\begin{array}{llllll}\text { Bokacheva } 2014 & 1.6 & 0.08 & 1.1 \% & 1.60[1.44,1.76] \\ \text { Cabuk 2015 } & 1.4 & 0.07 & 1.2 \% & 1.40[1.26,1.54]\end{array}$

$\begin{array}{lllll}\text { Cabuk } 2015 & 1.4 & 0.07 & 1.2 \% & 1.40[1.26,1.54]\end{array}$

$\begin{array}{lllll}\text { Cai 2014 } & 1.69 & 0.04 & 1.3 \% & 1.69[1.61,1.77] \\ \text { Caivano 2015a } & 2.06 & 0.03 & 1.3 \% & 2.06[2.00,2.12]\end{array}$

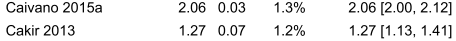

$\begin{array}{lllll}\text { Cakir } 2013 & 1.27 & 0.07 & 1.2 \% & 1.27[1.13,1.41] \\ \text { Chen } 2012 & 1.49 & 0.09 & 1.1 \% & 1.49[1.31,1.67]\end{array}$

$\begin{array}{lllll}\text { Chen } 2018 & 1.26 & 0.04 & 1.3 \% & 1.26[1.18,1.34]\end{array}$

Cheng 2013a $\quad \begin{array}{lllll}1.41 & 0.05 & 1.2 \% & 1.41[1.31,1.51]\end{array}$

$\begin{array}{lllll}\text { Cho } 2016 & 1.82 & 0.19 & 0.7 \% & 1.82[1.45,2.19]\end{array}$

$\begin{array}{lllll}\text { Choi 2018a } & 1.37 & 0.27 & 0.5 \% & 1.37[0.84,1.90]\end{array}$

de Almeida $2017 \quad \begin{array}{lllll}1.38 & 0.04 & 1.3 \% & 1.38[1.30,1.46]\end{array}$

$\begin{array}{lllll}\text { Eghtedari } 2016 & 1.46 & 0.07 & 1.2 \% & 1.46[1.32,1.60]\end{array}$

$\begin{array}{lllll}\text { Ertas } 2016 & 1.81 & 0.05 & 1.2 \% & 1.81[1.71,1.91]\end{array}$

$\begin{array}{lllll}\text { Ertas } 2018 & 1.13 & 0.03 & 1.3 \% & 1.13[1.07,1.19]\end{array}$

$\begin{array}{lllll}\text { Fan } 2018 & 1.38 & 0.02 & 1.3 \% & 1.38[1.34,1.42]\end{array}$

Fanariotis 2018 $\quad \begin{array}{lllll}1.35 & 0.04 & 1.3 \% & 1.35[1.27,1.43]\end{array}$

$\begin{array}{lllll}\text { Fornasa } 2011 & 1.68 & 0.02 & 1.3 \% & 1.68[1.64,1.72]\end{array}$

$\begin{array}{lrrrr}\text { Gity } 2018 & 1.49 & 0.04 & 1.3 \% & 1.49[1.41,1.57] \\ \text { Guatelli } 2017 & 1.5 & 0.04 & 1.3 \% & 1.50[1.42,1.58]\end{array}$

Hering 2016 $\quad$\begin{tabular}{rrrrr}
1.59 & 0.04 & $1.3 \%$ & $1.50[1.42,1.58]$ \\
\hline & 1.35 & 0.09 & $1.2 \%$ & $1.49[1.37,1.61]$
\end{tabular}

Hirano 2012b $\quad \begin{array}{lllll} & 1.49 & 0.06 & 1.2 \% & 1.49[1.37,1.61] \\ & 1.35 & 0.09 & 1.1 \% & 1.35[1.17,1.53]\end{array}$

Horvat $2018 \quad 1.53 \quad 0.02 \quad 1.3 \% \quad 1.53[1.49,1.57]$

Hu $2018 \quad 1.23 \quad 0.03 \quad 1.3 \% \quad 1.23[1.17,1.29]$

Huang $2018 \quad 1.44 \quad 0.06 \quad 1.2 \% \quad 1.44[1.32,1.56]$

Imamura $2010 \quad 1.19 \quad 0.07 \quad 1.2 \% \quad 1.19[1.05,1.33]$

Inoue $2011 \quad \begin{array}{rrrr}1.5 & 0.05 & 1.2 \% & 1.50[1.40,1.60]\end{array}$

\begin{tabular}{lllll} 
Janka 2014 & 1.89 & 0.07 & $1.2 \%$ & $1.89[1.75,2.03]$ \\
\hline & 1.68 & 0.03 & $1.3 \%$ & $1.68[1.62,1.74]$
\end{tabular}

Jin 2010

Kamitani 2014a

Kamitani 2014b

Kamitani 2014c

Kamitani 2014

Kanao 2018b

Khouli 2010

Kim 2018a

Kul 2018a

Kul 2018b

Kuroki $2004 a$
L 2018

Li 2018

Lo 2009

Lo 2009

Nogueira 2014a

Nogueira 2015

Ochi 2013

Ouyang 2014

Parsian 2012a

Parsian 2016

Partridge 2010a

Partridge 2010c

Partridge 2011

Pereira 2009

Ramirez-Galván 2015

Roknsharifi 2018a

Rubesova 2006

Sahin 2013

Satake 2011

Sharma 2016a

Song 2017

Sonmez 2012

Spick 2014

Spick 201

Tang 2018

Teruel 2016a

Teruel 2016b

Wan 2016

Wang 2016

Woodhams 2009a

Yabuuchi 2006

Yoo 2014

Zhang 2018

Zhao 2016

Zhao 2018

$\begin{array}{lll}1.61 & 0.07 & 1.2 \%\end{array}$

$\begin{array}{lll}1.61 & 0.07 & 1.2 \% \\ 1.58 & 0.08 & 1.1 \%\end{array}$

$1.68[1.62,1.74]$

$1.61[1.47,1.75]$

$1.58[1.42,1.74]$

$1.58[1.42,1.74]$

$\begin{array}{llll}1.54 & 0.06 & 1.2 \% & 1.54[1.42,1.66] \\ 1.47 & 0.08 & 1.1 \% & 1.47[1.31,1.63]\end{array}$

$\begin{array}{llll}1.45 & 0.14 & 0.9 \% & 1.45[1.18,1.72]\end{array}$

$\begin{array}{llll}1.45 & 0.14 & 0.9 \% & 1.45[1.18,1.72] \\ 1.77 & 0.04 & 1.3 \% & 1.77[1.69,1.85]\end{array}$

$\begin{array}{rrrr}1.77 & 0.04 & 1.3 \% & 1.77[1.69,1.85] \\ 1.1 & 0.07 & 1.2 \% & 1.10[0.96,1.24]\end{array}$

$\begin{array}{rrrr}1.1 & 0.07 & 1.2 \% & 1.10[0.96,1.24] \\ 136 & 0.03 & 1.3 \% & 1.36[1.30,1.42]\end{array}$

$\begin{array}{llll}1.36 & 0.03 & 1.3 \% & 1.36[1.30,1.42] \\ 1.29 & 0.04 & 1.3 \% & 1.29[1.21,1.37]\end{array}$

$\begin{array}{llll}1.29 & 0.04 & 1.3 \% & 1.29[1.21,1.37]\end{array}$

$\begin{array}{llll}1.42 & 0.05 & 1.2 \% & 1.42[1.32,1.52]\end{array}$

$\begin{array}{llll}1.49 & 0.2 & 0.7 \% & 1.49[1.10,1.88]\end{array}$

$\begin{array}{llll}1.46 & 0.06 & 1.2 \% & 1.46[1.34,1.58]\end{array}$

$\begin{array}{llll}1.49 & 0.04 & 1.3 \% & 1.49[1.41,1.57]\end{array}$

$\begin{array}{llll}1.47 & 0.09 & 1.1 \% & 1.47[1.29,1.65]\end{array}$

$\begin{array}{llll}1.66 & 0.1 & 1.1 \% & 1.66[1.46,1.86]\end{array}$

$\begin{array}{llll}1.78 & 0.04 & 1.3 \% & 1.78[1.70,1.86]\end{array}$

$\begin{array}{llll}1.74 & 0.07 & 1.2 \% & 1.74[1.60,1.88]\end{array}$

$\begin{array}{llll}1.21 & 0.04 & 1.3 \% & 1.21[1.13,1.29]\end{array}$

$\begin{array}{llll}1.83 & 0.15 & 0.9 \% & 1.83[1.54,2.12]\end{array}$

$\begin{array}{lllll}1.77 & 0.03 & 1.3 \% & 1.77[1.71,1.83]\end{array}$

$\begin{array}{llll}1.98 & 0.08 & 1.1 \% & 1.98[1.82,2.14]\end{array}$

$\begin{array}{llll}1.74 & 0.06 & 1.2 \% & 1.74[1.62,1.86]\end{array}$

$\begin{array}{llll}1.61 & 0.06 & 1.2 \% & 1.61[1.49,1.73]\end{array}$

$\begin{array}{llll}1.71 & 0.05 & 1.2 \% & 1.71[1.61,1.81]\end{array}$

$\begin{array}{llll}1.72 & 0.05 & 1.2 \% & 1.72[1.62,1.82]\end{array}$

$\begin{array}{llll}1.44 & 0.06 & 1.2 \% & 1.44[1.32,1.56]\end{array}$

$\begin{array}{llll}1.4 & 0.04 & 1.3 \% & 1.40[1.32,1.48]\end{array}$

$\begin{array}{llll}1.48 & 0.04 & 1.3 \% & 1.48[1.40,1.56]\end{array}$

$\begin{array}{llll}1.4 & 0.04 & 1.3 \% & 1.40[1.32,1.48\end{array}$

$1.90 .11 \quad 1.2 \%-1.51[1.37,1.65]$

$\begin{array}{llll}1.51 & 0.07 & 1.2 \% & 1.51[1,37,1.05] \\ 1.1 & 0.07 & 1.0 \% & 1.90[1.68,2.12]\end{array}$

$\begin{array}{llll}1.1 & 0.07 & 1.2 \% & 1.10 \\ 1.57 & 0.03 & 1.3 \% & 1.57 .96,1.24]\end{array}$

$\begin{array}{llll}1.57 & 0.03 & 1.3 \% & 1.57[1.51,1.63]\end{array}$

$\begin{array}{lllll}1.2 & 0.05 & 1.2 \% & 1.20[1.10,1.30]\end{array}$

$\begin{array}{llll}1.49 & 0.04 & 1.3 \% & 1.49[1.41,1.57]\end{array}$

$\begin{array}{lllll}1.53 & 0.04 & 1.3 \% & 1.53[1.45,1.61]\end{array}$

$\begin{array}{llll}1.38 & 0.06 & 1.2 \% & 1.38[1.26,1.50]\end{array}$

$\begin{array}{llll}1.37 & 0.06 & 1.2 \% & 1.37[1.25,1.49]\end{array}$

$\begin{array}{llll}1.66 & 0.04 & 1.3 \% & 1.66[1.58,1.74]\end{array}$

$\begin{array}{llll}1.69 & 0.04 & 1.3 \% & 1.69[1.61,1.77]\end{array}$

$\begin{array}{llll}1.27 & 0.09 & 1.1 \% & 1.27[1.09,1.45]\end{array}$

$\begin{array}{llll}1.22 & 0.04 & 1.3 \% & 1.22[1.14,1.30]\end{array}$

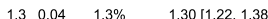

$\begin{array}{llll}1.3 & 0.04 & 1.3 \% & 1.30[1.22,1.38]\end{array}$

$\begin{array}{llll}1.87 & 0.03 & 1.3 \% & 1.87[1.81,1.93]\end{array}$

$\begin{array}{llll}1.42 & 0.06 & 1.2 \% & 1.42[1.30,1.54]\end{array}$

$\begin{array}{llll}1.43 & 0.04 & 1.3 \% & 1.43[1.35,1.51]\end{array}$

$\begin{array}{llll}1.45 & 0.08 & 1.1 \% & 1.45[1.29,1.61]\end{array}$

$\begin{array}{llll}1.69 & 0.09 & 1.1 \% & 1.69[1.51,1.87]\end{array}$

$\begin{array}{llll}1.52 & 0.04 & 1.3 \% & 1.52[1.44,1.60]\end{array}$

Total $(95 \% \mathrm{Cl})$

$100.0 \%$

$1.50[1.45,1.55]$

Heterogeneity: $\mathrm{Tau}^{2}=0.04 ; \mathrm{Chi}^{2}=1916.75$, df
IV, Random $95 \%$

\begin{tabular}{l|l} 
IV, Random, $95 \% \mathrm{Cl}$ & \\
& -
\end{tabular}

$\pi$

$+$

$\div$

$-$

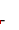

$+$

$-$

$+$

$+$

$+$

$+$

$-$

$+$

-

$\div$

$-$

$-$

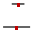

$+$

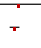

$+$

$+$

$+$

$-$

I

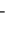

$-$

$-$

.

$r$

$-$

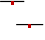

Fig. 4 Forrest plots of ADC values reported for benign breast lesions 


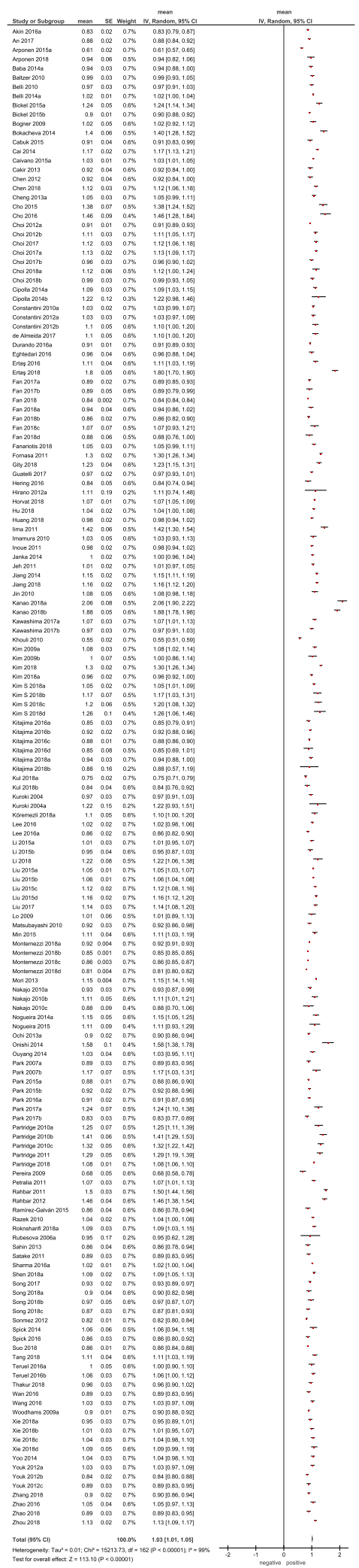

Fig. 5 Forrest plots of ADC values reported for malignant breast lesions significantly. However, there were no benign lesions under the ADC value of $1.00 \times 10^{-3} \mathrm{~mm}^{2} / \mathrm{s}$.

On the next step ADC values between malignant and benign breast lesions were compared in dependence on Tesla strength. Overall, 5854 lesions were investigated by $1.5 \mathrm{~T}$ scanners and 7061 lesions by $3 \mathrm{~T}$ scanners. In 932 lesions, the exact information regarding Tesla strength was not given. In the subgroup investigated by $1.5 \mathrm{~T}$ scanners, the mean ADC value of the malignant lesions $(n=4093)$ was $1.05 \times 10^{-3} \mathrm{~mm}^{2} / \mathrm{s}$ and the mean value of the benign lesions $(n=1761)$ was $1.54 \times 10^{-3}$ $\mathrm{mm}^{2} / \mathrm{s}$ (Fig. 7). The ADC values of the benign lesions were upper the ADC value of $1.00 \times 10^{-3} \mathrm{~mm}^{2} / \mathrm{s}$.

In the subgroup investigated by $3 \mathrm{~T}$ scanners, the mean ADC values of the malignant lesions $(n=5698)$ was $1.01 \times 10^{-3} \mathrm{~mm}^{2} / \mathrm{s}$ and the mean value of the benign lesions $(n=1363)$ was $1.46 \times 10^{-3} \mathrm{~mm}^{2} / \mathrm{s}$ (Fig. 8). Again in this subgroup, there were no benign lesions under the ADC value of $1.00 \times 10^{-3} \mathrm{~mm}^{2} / \mathrm{s}$.

Furthermore, cumulative ADC mean values were calculated in dependence on choice of upper b values. Overall, there were three large subgroups: b600 (426 malignant and 629 benign lesions), b750-850 (4015 malignant and 1230 benign lesions), and b1000 (4396 malignant and 1059 benign lesions). As shown in Fig. 9, the calculated $\mathrm{ADC}$ values of benign lesions were over the value $1.00 \times 10^{-3} \mathrm{~mm}^{2} / \mathrm{s}$ in every subgroup.

Finally, ADC values of malignant and benign lesions obtained by single measure in an isolated selected area or ROI (region of interest) and whole lesion measure were analyzed. Single ROI measure was performed for 10,882 lesions (8037 malignant and 2845 benign lesions) and whole lesion analysis was used in 2442 cases (1996 malignant and 446 benign lesions). Also in this subgroup, the ADC values of the benign lesions were above the ADC value of $1.00 \times 10^{-3} \mathrm{~mm}^{2} / \mathrm{s}$ (Fig. 10).

\section{Discussion}

The present analysis investigated ADC values in benign and malignant breast lesions in the largest cohort to date. It addresses a key question as to whether or not imaging parameters, in particular ADC can reflect histopathology of breast lesions. If so, then ADC can be used as a validated imaging biomarker in breast diagnostics. The possibility to stratify breast lesions on imaging is very important and can in particular avoid unnecessary biopsies. As shown in our analysis, previously, numerous studies investigated this question. Interestingly, most studies were reported in the years 2015-2018, which underlines the importance and actuality of the investigated clinical problem. However, as mentioned above, their results were inconsistent. There was no given threshold of an ADC value, which could be used in a clinical setting. 


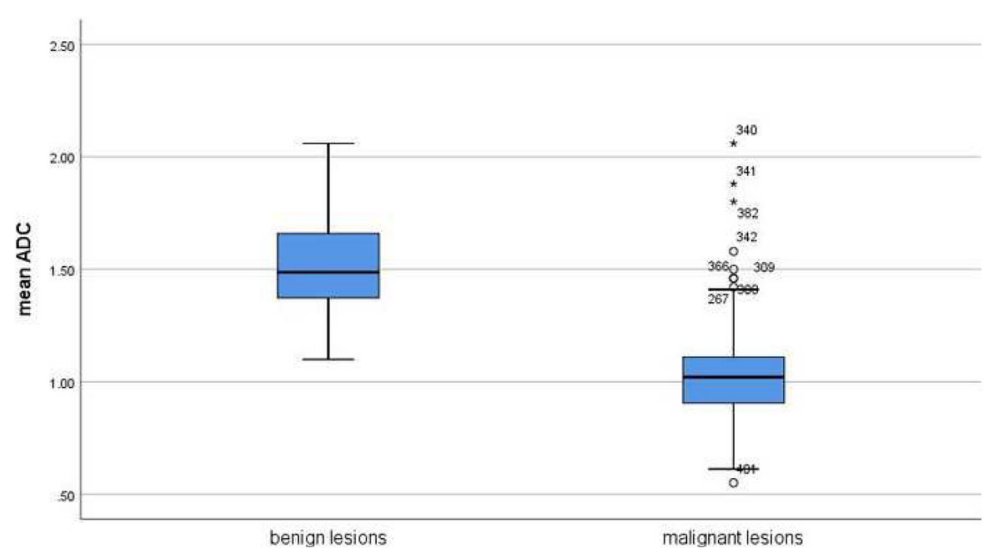

Fig. 6 Comparison of ADC values between malignant and benign breast lesions in the overall sample

Most reports indicated that malignant lesions have lower $\mathrm{ADC}$ values than benign findings but there was a broad spectrum of ADC threshold values to discriminate benign and malignant breast lesions. Furthermore, the published results were based on analyses of small numbers of lesions and, therefore, cannot be apply as evident. This limited the possibility to use $\mathrm{ADC}$ as an effective diagnostic tool in breast imaging.

Many causes can be responsible for the controversial data. There are no general recommendations regarding use of DWI in breast MRI i.e. Tesla strengths, choice of b values etc. It is known that all the technical parameters can influence DWI and ADC values [142]. Therefore, the reported data cannot apply for every situation. For example, ADC threshold values obtained on $1.5 \mathrm{~T}$ scanners cannot be transferred one-to-one to lesions on $3 \mathrm{~T}$.

Furthermore, previous reports had different proportions of benign and malignant lesions comprising various entities. It is well known that some benign breast lesions like abscesses have very low ADC values [143] and some breast cancers, such as mucinous carcinomas, show high ADC values [97, 144]. Furthermore, it has been also shown that invasive ductal and lobular carcinomas had statistically significant lower ADC values in comparison to ductal carcinoma in situ [145]. In addition, also carcinomas with different hormone receptor statuses demonstrate different ADC values $[115,119]$. Therefore, the exact proportion of analyzed breast lesions is very important. This suggests also that analyses of ADC values between malignant and benign breast lesions should include all possible lesions. All the facts can explain controversial results of the previous studies but cannot help in a real clinical situation on a patient level basis.

Recently, a meta-analysis about several DWI techniques like diffusion-weighted imaging, diffusion tensor imaging (DTI), and intravoxel incoherent motion (IVIM)

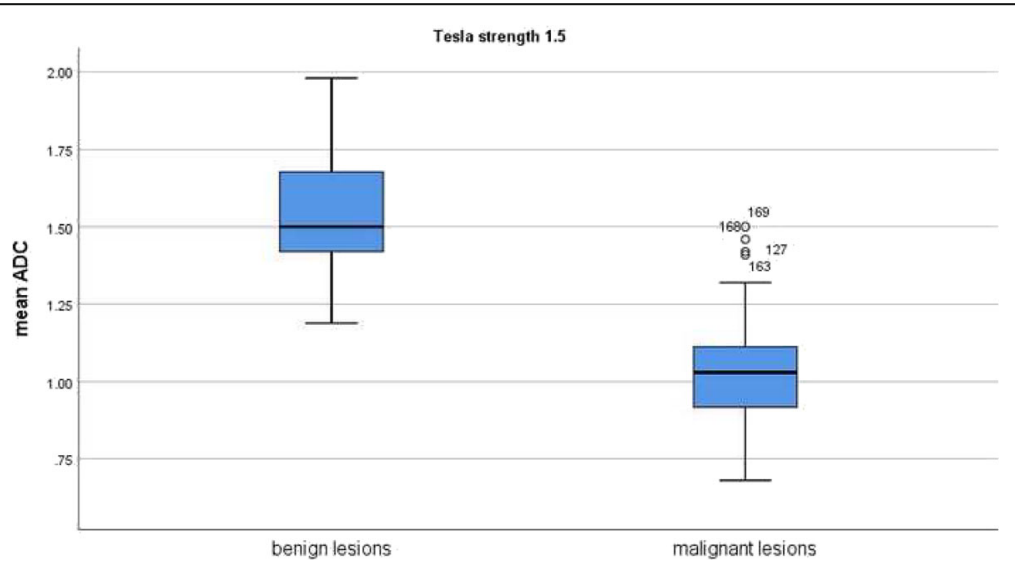

Fig. 7 Comparison of ADC values between malignant and benign breast lesions investigated by $1.5 T$ scanners 


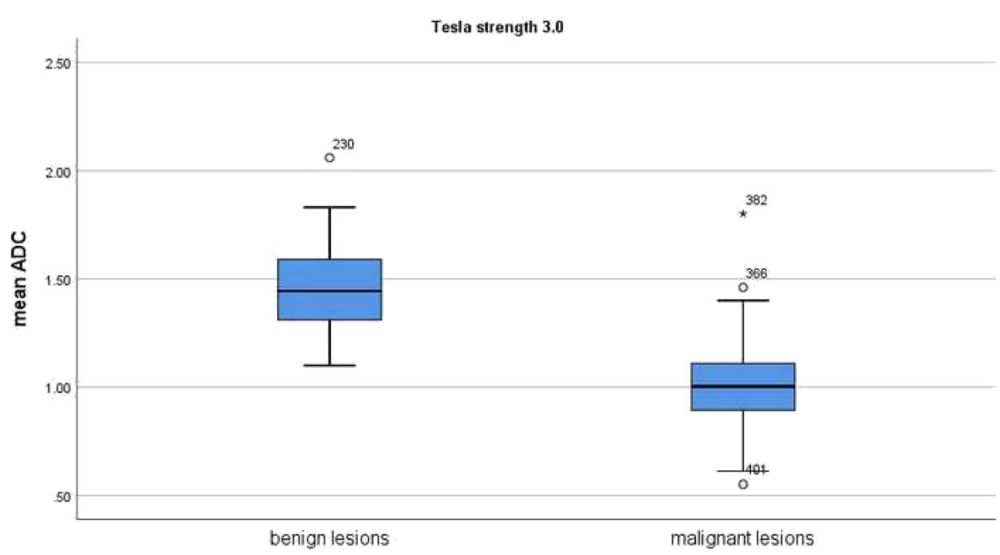

Fig. 8 Comparison of ADC values between malignant and benign breast lesions investigated by $3 T$ scanners

in breast imaging was published [146]. It was reported that these techniques were able to discriminate between malignant and benign lesions with a high sensitivity and specificity [146]. However, the authors included only studies with provided sensitivity/specificity data. Furthermore, no threshold values were calculated for discriminating malignant and benign breast lesions. Therefore, no recommendations regarding practical use of DWI in clinical setting could be given.

The present analysis included all published data about DWI findings/ADC values of different breast lesions and, therefore, in contrast to the previous reports, did not have selection bias. It showed that the mean values of benign breast lesions were no lower than $1.00 \times 10^{-3} \mathrm{~mm}^{2} / \mathrm{s}$. Therefore, this value can be used for distinguishing $\mathrm{BC}$ from benign findings. Furthermore, this result is independent from Tesla strength, measure methods and from the choice of $b$ values. This fact is very important and suggests that this cut-off can be used in every clinical situation.

We could not find a further threshold in the upper area of ADC values because malignant and benign lesions overlapped significantly. However, most malignant lesions have $\mathrm{ADC}$ values under $2.0 \times 10^{-3} \mathrm{~mm}^{2} / \mathrm{s}$. As shown, no real thresholds can be found in the area between 1.00 and $2.00 \times 10^{-3} \mathrm{~mm}^{2} / \mathrm{s}$ for discrimination malignant and benign breast lesions.

There are some inherent limitations of the present study to address. Firstly, the meta- analysis is based upon published results in the literature. There might be a certain publication bias because there is a trend to report positive or significant results; whereas studies with insignificant or negative results are often rejected or are not submitted. Secondly, there is the

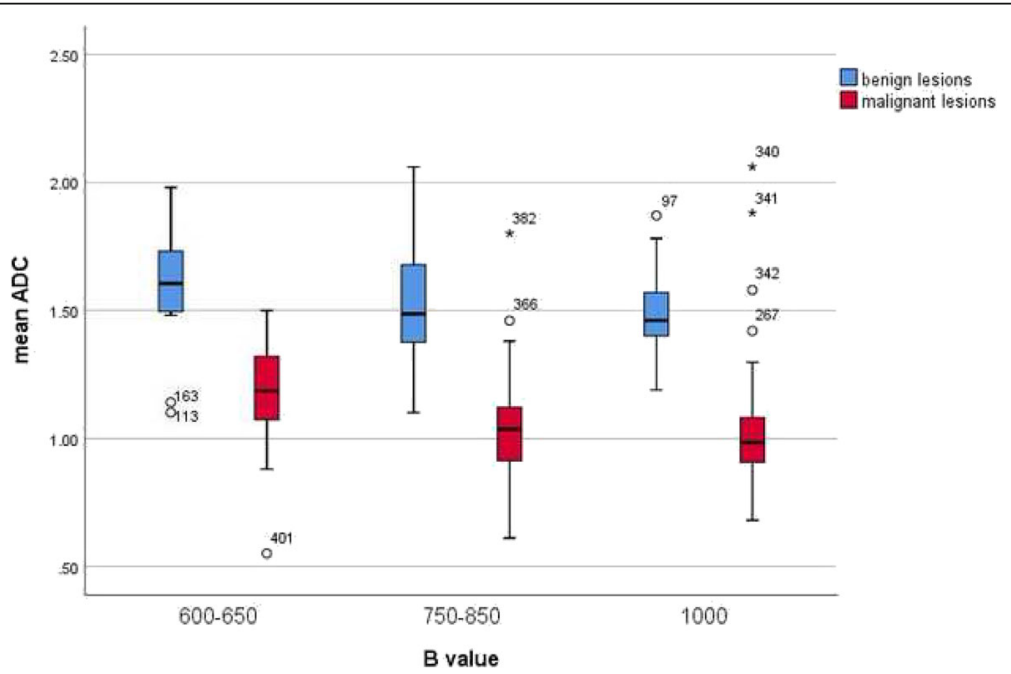

Fig. 9 Comparison of ADC values between malignant and benign breast lesions in dependence on the choice of $\mathrm{b}$ values 


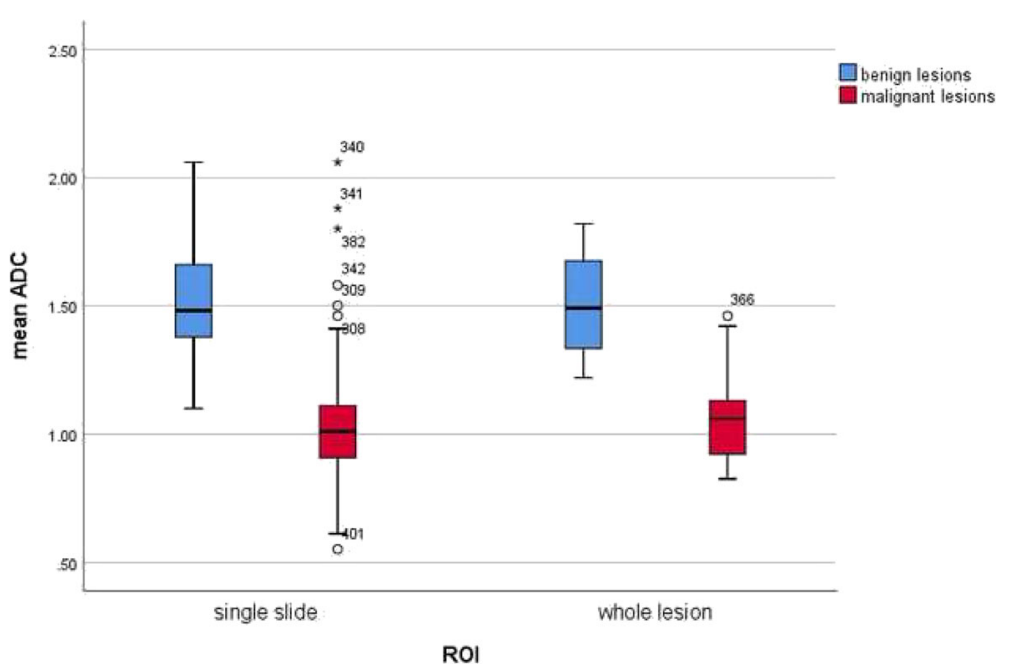

Fig. 10 Comparison of ADC values between malignant and benign breast lesions in dependence on measure methods

restriction to published papers in English language. Approximately 50 studies could therefore not be included in the present analysis. Thirdly, the study investigated the widely used DWI technique using $2 \mathrm{~b}$ values. However, more advanced MRI sequences, such as intravoxel-incoherent motion and diffusion-kurtosis imaging have been developed, which might show a better accuracy in discriminating benign from malignant tumors. Yet, there are few studies using these sequences and thus no comprehensive analysis can be made.

\section{Conclusion}

An ADC threshold of $1.0 \times 10^{-3} \mathrm{~mm}^{2} / \mathrm{s}$ can be recommended for distinguishing breast cancers from benign lesions. This result is independent on Tesla strength, choice of $\mathrm{b}$ values, and measure methods.

\section{Abbreviations}

ADC: Apparent diffusion coefficient; BC: Breast cancer; MRI: Magnetic resonance imaging

\section{Acknowledgements}

None.

\section{Authors' contributions}

AS, HJM, AW made substantial contributions to conception and design, or acquisition of data, or analysis and interpretation of data; HJM, AW been involved in drafting the manuscript or revising it critically for important intellectual content; HJM, AW given final approval of the version to be published. Each author should have participated sufficiently in the work to take public responsibility for appropriate portions of the content; and AS, HJM, AW agreed to be accountable for all aspects of the work in ensuring that questions related to the accuracy or integrity of any part of the work are appropriately investigated and resolved. All authors read and approved the final manuscript.

\section{Funding}

None.
Availability of data and materials

The datasets used and/or analyzed during the current study are available from the corresponding author on reasonable request.

Ethics approval and consent to participate

Not applicable.

\section{Consent for publication}

Not Applicable

\section{Competing interests}

The authors declare that they have no competing interests.

\section{Author details}

'Department of Diagnostic and Interventional Radiology, University of Leipzig, Liebigstr. 20, 04103 Leipzig, Germany. ²Department of Diagnostic and Interventional Radiology, Ulm University Medical Center, Albert-Einstein-Allee 23, 89081 Ulm, Germany. ${ }^{3}$ Institute of Medical Epidemiology, Biostatistics, and Informatics, Martin-Luther-University Halle-Wittenberg, Magdeburger Str. 8, 06097 Halle, Germany.

Received: 7 May 2019 Accepted: 24 September 2019

Published online: 15 October 2019

\section{References}

1. Mann RM, Kuhl CK, Kinkel K, Boetes C. Breast MRl: guidelines from the European society of breast imaging. Eur Radiol. 2008;18(7):1307-18.

2. Bluemke DA, Gatsonis CA, Chen MH, et al. Magnetic resonance imaging of the breast prior to biopsy. JAMA. 2004;292(22):2735-42.

3. Rahbar H, Partridge SC. Multiparametric MR imaging of breast cancer. Magn Reson Imaging Clin North Am. 2016;24(1):223-38.

4. Johansen $R$, Jensen $L R$, Rydland J, et al. Predicting survival and early clinical response to primary chemotherapy for patients with locally advanced breast cancer using DCE-MRI. J Magn Reson Imaging. 2009:29(6):1300-7.

5. Houssami N, Ciatto S, Macaskill P, et al. Accuracy and surgical impact of magnetic resonance imaging in breast cancer staging: systematic review and meta-analysis in detection of multifocal and multicentric cancer. J Clin Oncol. 2008;26(19):3248-58.

6. Chen X, Li WL, Zhang YL, et al. Meta-analysis of quantitative diffusionweighted MR imaging in the differential diagnosis of breast lesions. BMC Cancer. 2010;10:693.

7. Altay C, Balci P, Altay S, et al. Diffusion-weighted MR imaging: role in the differential diagnosis of breast lesions. JBR-BTR. 2014;97(4):211-6.

8. Zhang L, Tang M, Min Z, et al. Accuracy of combined dynamic contrastenhanced magnetic resonance imaging and diffusion-weighted imaging for breast cancer detection: a meta-analysis. Acta Radiol. 2016;57(6):651-60. 
9. Fornasa F. Diffusion-weighted magnetic resonance imaging: what makes water run fast or slow? J Clin Imaging Sci. 2011;1:27.

10. Bozgeyik Z, Onur MR, Poyraz AK. The role of diffusion weighted magnetic resonance imaging in oncologic settings. Quant Imaging Med Surg. 2013; 3(5):269-7.

11. Surov A, Meyer HJ, Wienke A. Correlation between apparent diffusion coefficient (ADC) and cellularity is different in several tumors: a Metaanalysis. Oncotarget. 2017;8(35):59492-9.

12. Surov A, Meyer HJ, Wienke A. Correlation between apparent diffusion coefficient (ADC) and KI 67 in different tumors: a Meta-analysis. Part 1: ADCmean. Oncotarget. 2017;8(43):75434-44.

13. Aribal E, Asadov R, Ramazan A, et al. Multiparametric breast MRI with 3T: Effectivity of combination of contrast enhanced MRI, DWI and $1 \mathrm{H}$ single voxel spectroscopy in differentiation of breast tumors. Eur J Radiol. 2016; 85(5):979-86.

14. Arponen O, Sudah M, Masarwah A, et al. Diffusion-Weighted Imaging in 3.0 Tesla Breast MRI: Diagnostic Performance and Tumor Characterization Using Small Subregions vs. Whole Tumor Regions of Interest. PLoS One. 2015; 10(10):e0138702.

15. Cakir O, Arslan A, Inan N, et al. Comparison of the diagnostic performances of diffusion parameters in diffusion weighted imaging and diffusion tensor imaging of breast lesions. Eur J Radiol. 2013;82(12):e801-6.

16. Moher D, Liberati A, Tetzlaff J, Altman DG. Preferred reporting items for systematic reviews and meta-analyses: the PRISMA statement. PLoS Med. 2009;6(7):e1000097.

17. Whiting PF, Rutjes AW, Westwood ME, et al. QUADAS-2: a revised tool for the quality assessment of diagnostic accuracy studies. Ann Intern Med. 2011;155(8):529-36.

18. Leeflang MM, Deeks JJ, Gatsonis C, Bossuyt PM. Systematic reviews of diagnostic test accuracy. Ann Intern Med. 2008;149(12):889-97.

19. Zamora J, Abraira V, Muriel A, et al. Meta-DiSc: a software for meta-analysis of test accuracy data. BMC Med Res Methodol. 2006;6:31.

20. DerSimonian R, Laird N. Meta-analysis in clinical trials. Control Clin Trials. 1986;7(3):177-88.

21. Akın Y, Uğurlu MÜ, Kaya H, Arıbal E. Diagnostic value of diffusion-weighted imaging and apparent diffusion coefficient values in the differentiation of breast lesions, Histpathologic subgroups and Correlatıon with Prognostıc factors using 3.0 tesla MR. J Breast Health. 2016;12(3):123-32.

22. An YY, Kim SH, Kang BJ. Differentiation of malignant and benign breast lesions: Added value of the qualitative analysis of breast lesions on diffusion-weighted imaging (DWI) using readout-segmented echo-planar imaging at 3.0 T. PLoS One. 2017;12(3):e0174681.

23. Arponen $\mathrm{O}$, Sudah M, Sutela A, et al. Gadoterate meglumine decreases ADC values of breast lesions depending on the $b$ value combination. Sci Rep. 2018:8(1):87.

24. Baba S, Isoda T, Maruoka Y, et al. Diagnostic and prognostic value of pretreatment SUV in 18F-FDG/PET in breast cancer: comparison with apparent diffusion coefficient from diffusion-weighted MR imaging. J Nucl Med. 2014;55(5):736-42.

25. Baltzer PA, Benndorf M, Dietzel M, et al. Sensitivity and specificity of unenhanced MR mammography (DWI combined with T2-weighted TSE imaging, ueMRM) for the differentiation of mass lesions. Eur Radiol. 2010; 20(5):1101-10.

26. Belli $P$, Costantini $M$, Bufi $E$, et al. Diffusion magnetic resonance imaging in breast cancer characterisation: correlations between the apparent diffusion coefficient and major prognostic factors. Radiol Med. 2015;120(3):268-76

27. Belli $P$, Costantini $M$, Bufi $E$, et al. Diffusion-weighted imaging in breast lesion evaluation. Radiol Med. 2010;115(1):51-69.

28. Bickel H, Pinker-Domenig K, Bogner W, et al. Quantitative apparent diffusion coefficient as a noninvasive imaging biomarker for the differentiation of invasive breast cancer and ductal carcinoma in situ. Investig Radiol. 2015; 50(2):95-100.

29. Bogner W, Gruber S, Pinker K, et al. Diffusion-weighted MR for differentiation of breast lesions at 3.0 T: how does selection of diffusion protocols affect diagnosis? Radiology. 2009;253(2):341-51.

30. Bokacheva L, Kaplan JB, Giri DD, et al. Intravoxel incoherent motion diffusion-weighted MRI at 3.0 T differentiates malignant breast lesions from benign lesions and breast parenchyma. J Magn Reson Imaging. 2014;40(4): 813-23.

31. Cabuk G, Nass Duce M, Özgür A, et al. The diagnostic value of diffusionweighted imaging and the apparent diffusion coefficient values in the differentiation of benign and malignant breast lesions. J Med Imaging Radiat Oncol. 2015;59(2):141-8.

32. Cai $H$, Peng $Y, O u ~ C$, et al. Diagnosis of breast masses from dynamic contrast-enhanced and diffusion-weighted MR: a machine learning approach. PLoS One. 2014;9(1):e87387.

33. Caivano R, Villonio A, D'Antuono F, et al. Diffusion weighted imaging and apparent diffusion coefficient in 3 tesla magnetic resonance imaging of breast lesions. Cancer Investig. 2015;33(5):159-64.

34. Chen $X, H e X J$, Jin $R$, et al. Conspicuity of breast lesions at different b values on diffusion-weighted imaging. BMC Cancer. 2012;12:334.

35. Chen Y, Wu B, Liu H, et al. Feasibility study of dual parametric 2D histogram analysis of breast lesions with dynamic contrast-enhanced and diffusionweighted MRI. J Transl Med. 2018;16(1):325.

36. Cheng $L$, Bai $Y$, Zhang J, et al. Optimization of apparent diffusion coefficient measured by diffusion-weighted MRI for diagnosis of breast lesions presenting as mass and non-mass-like enhancement. Tumour Biol. 2013; 34(3):1537-45.

37. Cho GY, Moy L, Kim SG, et al. Evaluation of breast cancer using intravoxel incoherent motion (IVIM) histogram analysis: comparison with malignant status, histological subtype, and molecular prognostic factors. Eur Radiol. 2016;26(8):2547-58.

38. Cho GY, Moy L, Kim SG, et al. Comparison of contrast enhancement and diffusion-weighted magnetic resonance imaging in healthy and cancerous breast tissue. Eur J Radiol. 2015;84(10):1888-93.

39. Choi BB, Kim SH, Park CS, Jung NY. Correlation of prognostic factors of invasive lobular carcinoma with ADC value of DWI and SUVMax of FDG-PET. Chonnam Med J. 2017;53(2):133-9.

40. Choi JH, Lim I, Noh WC, et al. Prediction of tumor differentiation using sequential PET/CT and MRI in patients with breast cancer. Ann Nucl Med. 2018;32(6):389-97.

41. Choi SY, Chang YW, Park HJ, et al. Correlation of the apparent diffusion coefficiency values on diffusion-weighted imaging with prognostic factors for breast cancer. Br J Radiol. 2012;85(1016):e474-9.

42. Choi Y, Kim SH, Youn IK, et al. Rim sign and histogram analysis of apparent diffusion coefficient values on diffusion-weighted MRI in triple-negative breast cancer: comparison with ER-positive subtype. PLoS One. 2017;12(5): e0177903.

43. Cipolla V, Santucci D, Guerrieri D, et al. Correlation between 3T apparent diffusion coefficient values and grading of invasive breast carcinoma. Eur J Radiol. 2014:83(12):2144-50.

44. Costantini M, Belli P, Distefano D, et al. Magnetic resonance imaging features in triple-negative breast cancer: comparison with luminal and HER2-overexpressing tumors. Clin Breast Cancer. 2012;12(5):331-9.

45. Costantini $M$, Belli $P$, Rinaldi $P$, et al. Diffusion-weighted imaging in breast cancer: relationship between apparent diffusion coefficient and tumour aggressiveness. Clin Radiol. 2010;65(12):1005-12.

46. de Almeida JRM, Gomes AB, Barros TP, et al. Diffusion-weighted imaging of suspicious (BI-RADS 4) breast lesions: stratification based on histopathology. Radiol Bras. 2017:50(3):154-61.

47. Durando M, Gennaro L, Cho GY, et al. Quantitative apparent diffusion coefficient measurement obtained by 3.0Tesla MRI as a potential noninvasive marker of tumor aggressiveness in breast cancer. Eur J Radiol. 2016;85(9):1651-8.

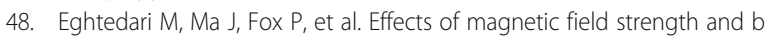
value on the sensitivity and specificity of quantitative breast diffusionweighted MRI. Quant Imaging Med Surg. 2016;6(4):374-80.

49. Ertas $G$, Onaygil $C$, Akin $Y$, et al. Quantitative differentiation of breast lesions at $3 \mathrm{~T}$ diffusion-weighted imaging (DWI) using the ratio of distributed diffusion coefficient (DDC). J Magn Reson Imaging. 2016;44(6):1633-41.

50. Ertaş G, Onaygil C, Buğdaycı O, Arıbal E. Dual-phase ADC modelling of breast masses in diffusion-weighted imaging: comparison with Histopathologic findings. Eur J Breast Health. 2018;14(2):85-92.

51. Fan $M, H e T$, Zhang $P$, et al. Diffusion-weighted imaging features of breast tumours and the surrounding stroma reflect intrinsic heterogeneous characteristics of molecular subtypes in breast cancer. NMR Biomed. 2018;31(2) https://doi.org/10.1002/nbm.3869

52. Fan WX, Chen XF, Cheng FY, et al. Retrospective analysis of the utility of multiparametric MRI for differentiating between benign and malignant breast lesions in women in China. Medicine (Baltimore). 2018;97(4):e9666. 
53. Fan M, He T, Zhang $P$, et al. Heterogeneity of diffusion-weighted imaging in tumours and the surrounding Stroma for prediction of Ki-67 proliferation status in breast Cancer. Sci Rep. 2017;7(1):2875.

54. Fanariotis M, Vassiou K, Tsougos I, Fezoulidis I. Reproducibility of apparent diffusion coefficient measurements evaluated with different workstations. Clin Radiol. 2018;73(2):141-8

55. Fornasa F, Pinali L, Gasparini A, et al. Diffusion-weighted magnetic resonance imaging in focal breast lesions: analysis of 78 cases with pathological correlation. Radiol Med. 2011;116(2):264-75.

56. Gity M, Moradi B, Arami R, et al. Two different methods of region-of-interest placement for differentiation of benign and malignant breast lesions by apparent diffusion coefficient value. Asian Pac J Cancer Prev. 2018;19(10):2765-70.

57. Guatelli CS, Bitencourt AGV, Osório CABT, et al. Can diffusion-weighted imaging add information in the evaluation of breast lesions considered suspicious on magnetic resonance imaging? Radiol Bras. 2017:50(5):291-8.

58. Hering J, Laun FB, Lederer W, et al. Applicability and discriminative value of a semiautomatic three-dimensional spherical volume for the assessment of the apparent diffusion coefficient in suspicious breast lesions-feasibility study. Clin Imaging. 2016;40(6):1280-5.

59. Hirano M, Satake H, Ishigaki S, et al. Diffusion-weighted imaging of breast masses: comparison of diagnostic performance using various apparent diffusion coefficient parameters. AJR Am J Roentgenol. 2012;198(3):717-22.

60. Horvat JV, Durando M, Milans S, et al. Apparent diffusion coefficient mapping using diffusion-weighted MRI: impact of background parenchymal enhancement, amount of fibroglandular tissue and menopausal status on breast cancer diagnosis. Eur Radiol. 2018;28(6):2516-24.

61. Hu B, Xu K, Zhang Z, et al. A radiomic nomogram based on an apparent diffusion coefficient map for differential diagnosis of suspicious breast findings. Chin J Cancer Res. 2018;30(4):432-8.

62. Huang $Y$, Lin $Y, H u$ W, et al. Diffusion kurtosis at 3.0T as an in vivo imaging marker for breast Cancer characterization: correlation with prognostic factors. J Magn Reson Imaging. 2019;49(3):845-56.

63. lima M, Le Bihan D, Okumura R, et al. Apparent diffusion coefficient as an MR imaging biomarker of low-risk ductal carcinoma in situ: a pilot study. Radiology. 2011;260(2):364-72.

64. Imamura T, Isomoto I, Sueyoshi E, et al. Diagnostic performance of ADC for nonmass-like breast lesions on MR imaging. Magn Reson Med Sci. 2010;9(4):217-25.

65. Inoue K, Kozawa E, Mizukoshi W, et al. Usefulness of diffusion-weighted imaging of breast tumors: quantitative and visual assessment. Jpn J Radiol. 2011;29(6):429-36.

66. Janka R, Hammon M, Geppert C, et al. Diffusion-weighted MR imaging of benign and malignant breast lesions before and after contrast enhancement. Rofo. 2014;186(2):130-5.

67. Jeh SK, Kim SH, Kim HS, et al. Correlation of the apparent diffusion coefficient value and dynamic magnetic resonance imaging findings with prognostic factors in invasive ductal carcinoma. J Magn Reson Imaging. 2011;33(1):102-9.

68. Jiang $X$, Xie F, Liu L, et al. Discrimination of malignant and benign breast masses using automatic segmentation and features extracted from dynamic contrast-enhanced and diffusion-weighted MRI. Oncol Lett. 2018;16(2):1521-8.

69. Jiang $X Y$, Xie QZ, Cao XS, et al. Value of diffusion weighted imaging in the differential diagnosis of benign and malignant breast lesions at 3.0T MRI. Genet Mol Res. 2014;13(3):7773-9.

70. Jin G, An N, Jacobs MA, Li K. The role of parallel diffusion-weighted imaging and apparent diffusion coefficient (ADC) map values for evaluating breast lesions: preliminary results. Acad Radiol. 2010;17(4):456-63.

71. Kanao S, Kataoka M, lima M, et al. Differentiating benign and malignant inflammatory breast lesions: value of $\mathrm{T} 2$ weighted and diffusion weighted MR images. Magn Reson Imaging. 2018;50:38-44.

72. Kawashima H, Miyati T, Ohno N, et al. Differentiation between luminal-a and luminal-B breast Cancer using Intravoxel incoherent motion and dynamic contrast-enhanced magnetic resonance imaging. Acad Radiol. 2017;24(12): 1575-81.

73. Ei Khouli RH, Jacobs MA, Mezban SD, et al. Diffusion-weighted imaging improves the diagnostic accuracy of conventional 3.0-T breast MR imaging. Radiology. 2010;256(1):64-73.

74. Kim JY, Kim JJ, Lee JW, et al. Risk stratification of ductal carcinoma in situ using whole-lesion histogram analysis of the apparent diffusion coefficient. Eur Radiol. 2019;29(2):485-93.

75. Kim KW, Kuzmiak CM, Kim YJ, et al. Diagnostic usefulness of combination of diffusion-weighted imaging and T2WI, including apparent diffusion coefficient in breast lesions: assessment of histologic grade. Acad Radiol. 2018;25(5):643-52

76. Kim SY, Shin J, Kim DH, et al. Correlation between electrical conductivity and apparent diffusion coefficient in breast cancer: effect of necrosis on magnetic resonance imaging. Eur Radiol. 2018;28(8):3204-14.

77. Kim SH, Cha ES, Kim HS, et al. Diffusion-weighted imaging of breast cancer: correlation of the apparent diffusion coefficient value with prognostic factors. J Magn Reson Imaging. 2009;30(3):615-20.

78. Kitajima K, Miyoshi Y, Yamano T, et al. Prognostic value of FDG-PET and DWI in breast cancer. Ann Nucl Med. 2018;32(1):44-53.

79. Kitajima K, Yamano T, Fukushima K, et al. Correlation of the SUVmax of FDGPET and ADC values of diffusion-weighted MR imaging with pathologic prognostic factors in breast carcinoma. Eur J Radiol. 2016;85(5):943-9.

80. Köremezli Keskin N, Balcı P, Başara Akın I, et al. Detection of the differences in the apparent diffusion coefficient values in different histopathological types of malignant breast lesions and comparison of cellular region/ stroma ratio and histopathological results. Turk J Med Sci. 2018;48(4):817-25.

81. Kul S, Metin Y, Kul M, et al. Assessment of breast mass morphology with diffusion-weighted MRl: beyond apparent diffusion coefficient. J Magn Reson Imaging. 2018;48(6):1668-77.

82. Kuroki Y, Nasu K, Kuroki S, et al. Diffusion-weighted imaging of breast cancer with the sensitivity encoding technique: analysis of the apparent diffusion coefficient value. Magn Reson Med Sci. 2004;3(2):79-85.

83. Lee CW, Wu HK, Lai HW, et al. Preoperative clinicopathologic factors and breast magnetic resonance imaging features can predict ductal carcinoma in situ with invasive components. Eur J Radiol. 2016;85(4):780-9.

84. Lee HS, Kim SH, Kang BJ, et al. Perfusion Parameters in Dynamic Contrastenhanced MRI and Apparent Diffusion Coefficient Value in Diffusion-weighted MRI:: Association with Prognostic Factors in Breast Cancer. Acad Radiol. 2016; 23(4):446-56.

85. Li L, Wang K, Sun X, et al. Parameters of dynamic contrast-enhanced MRI as imaging markers for angiogenesis and proliferation in human breast cancer. Med Sci Monit. 2015;21:376-82.

86. Liu HL, Zong $\mathrm{M}$, Wei $\mathrm{H}$, et al. Preoperative predicting malignancy in breast mass-like lesions: value of adding histogram analysis of apparent diffusion coefficient maps to dynamic contrast-enhanced magnetic resonance imaging for improving confidence level. Br J Radiol. 2017;90(1079):20170394.

87. Liu S, Ren R, Chen Z, et al. Diffusion-weighted imaging in assessing pathological response of tumor in breast cancer subtype to neoadjuvant chemotherapy. J Magn Reson Imaging. 2015;42(3):779-87.

88. Lo GG, Ai V, Chan JK, et al. Diffusion-weighted magnetic resonance imaging of breast lesions: first experiences at 3 T. J Comput Assist Tomogr. 2009;33(1):63-9.

89. Matsubayashi RN, Fujii T, Yasumori K, et al. Apparent Diffusion Coefficient in Invasive Ductal Breast Carcinoma: Correlation with Detailed Histologic Features and the Enhancement Ratio on Dynamic Contrast-Enhanced MR Images. J Oncol. 2010;2010. https://doi.org/10.1155/2010/821048

90. Min Q, Shao K, Zhai L, et al. Differential diagnosis of benign and malignant breast masses using diffusion-weighted magnetic resonance imaging. World J Surg Oncol. 2015;13:32.

91. Montemezzi S, Camera L, Giri MG, et al. Is there a correlation between $3 T$ multiparametric MRI and molecular subtypes of breast cancer? Eur J Radiol. 2018;108:120-7.

92. Mori N, Ota H, Mugikura S, et al. Detection of invasive components in cases of breast ductal carcinoma in situ on biopsy by using apparent diffusion coefficient MR parameters. Eur Radiol. 2013;23(10):2705-12.

93. Nakajo M, Kajiya Y, Kaneko T, et al. FDG PET/CT and diffusion-weighted imaging for breast cancer: prognostic value of maximum standardized uptake values and apparent diffusion coefficient values of the primary lesion. Eur J Nucl Med Mol Imaging. 2010;37(11):2011-20.

94. Nogueira L, Brandão S, Matos E, et al. Improving malignancy prediction in breast lesions with the combination of apparent diffusion coefficient and dynamic contrast-enhanced kinetic descriptors. Clin Radiol. 2015;70(9):1016-25.

95. Nogueira L, Brandão S, Matos E, et al. Diffusion-weighted imaging: determination of the best pair of b-values to discriminate breast lesions. $\mathrm{Br}$ J Radiol. 2014;87(1039):20130807.

96. Ochi M, Kuroiwa T, Sunami S, et al. Diffusion-weighted imaging (b value = $1500 \mathrm{~s} / \mathrm{mm}(2))$ is useful to decrease false-positive breast cancer cases due to fibrocystic changes. Breast Cancer. 2013;20(2):137-44.

97. Onishi N, Kanao S, Kataoka M, et al. Apparent diffusion coefficient as a potential surrogate marker for Ki-67 index in mucinous breast carcinoma. J Magn Reson Imaging. 2015;41(3):610-5. 
98. Ouyang Z, Ouyang $Y$, Zhu M, et al. Diffusion-weighted imaging with fat suppression using short-tau inversion recovery: clinical utility for diagnosis of breast lesions. Clin Radiol. 2014;69(8):e337-44.

99. Park GE, Kim SH, Kim EJ, et al. Histogram analysis of volume-based apparent diffusion coefficient in breast cancer. Acta Radiol. 2017;58(11):1294-302.

100. Park EK, Cho KR, Seo BK, et al. Additional value of diffusion-weighted imaging to evaluate prognostic factors of breast Cancer: correlation with the apparent diffusion coefficient. Iran J Radiol. 2016;13(1):e33133.

101. Park MJ, Cha ES, Kang BJ, et al. The role of diffusion-weighted imaging and the apparent diffusion coefficient (ADC) values for breast tumors. Korean J Radiol. 2007;8(5):390-6.

102. Park SH, Choi HY, Hahn SY. Correlations between apparent diffusion coefficient values of invasive ductal carcinoma and pathologic factors on diffusionweighted MRI at 3.0 tesla. J Magn Reson Imaging. 2015;41(1):175-82.

103. Parsian S, Rahbar H, Allison KH, et al. Nonmalignant breast lesions: ADCs of benign and high-risk subtypes assessed as false-positive at dynamic enhanced MR imaging. Radiology. 2012;265(3):696-706.

104. Parsian S, Giannakopoulos NV, Rahbar H, et al. Diffusion-weighted imaging reflects variable cellularity and stromal density present in breast fibroadenomas. Clin Imaging. 2016;40(5):1047-54.

105. Partridge SC, Zhang Z, Newitt DC, et al. Diffusion-weighted MRI findings predict pathologic response in Neoadjuvant treatment of breast Cancer: the ACRIN 6698 Multicenter trial. Radiology. 2018;289(3):618-27.

106. Partridge SC, Rahbar H, Murthy R, et al. Improved diagnostic accuracy of breast MRI through combined apparent diffusion coefficients and dynamic contrast-enhanced kinetics. Magn Reson Med. 2011;65(6):1759-67.

107. Partridge SC, Mullins CD, Kurland BF, et al. Apparent diffusion coefficient values for discriminating benign and malignant breast MRI lesions: effects of lesion type and size. AJR Am J Roentgenol. 2010;194(6):1664-73.

108. Partridge SC, Demartini WB, Kurland BF, et al. Differential diagnosis of mammographically and clinically occult breast lesions on diffusionweighted MRI. J Magn Reson Imaging. 2010;31(3):562-70.

109. Pereira FP, Martins G, Figueiredo E, et al. Assessment of breast lesions with diffusion-weighted MRI: comparing the use of different $b$ values. AJR Am Roentgenol. 2009;193(4):1030-5.

110. Petralia G, Bonello L, Summers $P$, et al. Intraobserver and interobserver variability in the calculation of apparent diffusion coefficient (ADC) from diffusion-weighted magnetic resonance imaging (DW-MRI) of breast tumours. Radiol Med. 2011;116(3):466-76.

111. Rahbar H, Partridge SC, Eby PR, et al. Characterization of ductal carcinoma in situ on diffusion weighted breast MRI. Eur Radiol. 2011;21(9):2011-9.

112. Rahbar H, Partridge SC, Demartini WB, et al. In vivo assessment of ductal carcinoma in situ grade: a model incorporating dynamic contrast-enhanced and diffusion-weighted breast MR imaging parameters. Radiology. 2012; 263(2):374-82.

113. Ramírez-Galván YA, Cardona-Huerta S, Ibarra-Fombona E, Elizondo-Riojas G. Apparent diffusion coefficient (ADC) value to evaluate BI-RADS 4 breast lesions: correlation with pathological findings. Clin Imaging. 2015;39(1):51-5.

114. Razek AA, Gaballa G, Denewer A, Nada N. Invasive ductal carcinoma: correlation of apparent diffusion coefficient value with pathological prognostic factors. NMR Biomed. 2010;23(6):619-23.

115. Roknsharifi S, Fishman MDC, Agarwal MD, et al. The role of diffusion weighted imaging as supplement to dynamic contrast enhanced breast MRI: Can it help predict malignancy, histologic grade and recurrence? Acad Radiol. 2019;26(7):923-29.

116. Rubesova E, Grell AS, De Maertelaer V, et al. Quantitative diffusion imaging in breast cancer: a clinical prospective study. J Magn Reson Imaging. 2006; 24(2):319-24.

117. Şahin C, Aribal E. The role of apparent diffusion coefficient values in the differential diagnosis of breast lesions in diffusion-weighted MRI. Diagn Interv Radiol. 2013;19(6):457-62.

118. Satake $H$, Nishio A, lkeda M, et al. Predictive value for malignancy of suspicious breast masses of BI-RADS categories 4 and 5 using ultrasound elastography and MR diffusion-weighted imaging. AJR Am J Roentgenol. 2011;196(1):202-9.

119. Sharma U, Sah RG, Agarwal K, et al. Potential of diffusion-weighted imaging in the characterization of malignant, benign, and healthy breast tissues and molecular subtypes of breast Cancer. Front Oncol. 2016;6:126.

120. Shen $L$, Zhou G, Tong T, et al. ADC at $3.0 \mathrm{~T}$ as a noninvasive biomarker for preoperative prediction of Ki67 expression in invasive ductal carcinoma of breast. Clin Imaging. 2018;52:16-22.
121. Song SE, Cho KR, Seo BK, et al. Intravoxel incoherent motion diffusionweighted MRI of invasive breast cancer: correlation with prognostic factors and kinetic features acquired with computer-aided diagnosis. J Magn Reson Imaging. 2019:49(1):118-30.

122. Song SE, Park EK, Cho KR, et al. Additional value of diffusion-weighted imaging to evaluate multifocal and multicentric breast cancer detected using pre-operative breast MRI. Eur Radiol. 2017;27(11):4819-27.

123. Sonmez G, Cuce F, Mutlu H, et al. Value of diffusion-weighted MRI in the differentiation of benign and malign breast lesions. Wien Klin Wochenschr. 2011;123(21-22):655-61.

124. Spick C, Bickel H, Pinker K, et al. Diffusion-weighted MRI of breast lesions: a prospective clinical investigation of the quantitative imaging biomarker characteristics of reproducibility, repeatability, and diagnostic accuracy. NMR Biomed. 2016;29(10):1445-53.

125. Spick C, Pinker-Domenig K, Rudas M, et al. MRl-only lesions: application of diffusion-weighted imaging obviates unnecessary MR-guided breast biopsies. Eur Radiol. 2014;24(6):1204-10.

126. Suo S, Zhang D, Cheng F, et al. Added value of mean and entropy of apparent diffusion coefficient values for evaluating histologic phenotypes of invasive ductal breast cancer with MR imaging. Eur Radiol. 2019;29(3):1425-34.

127. Tang $Q, L i$ Q, Xie $D$, et al. An apparent diffusion coefficient histogram method versus a traditional 2-dimensional measurement method for identifying non-puerperal mastitis from breast Cancer at 3.0 T. J Comput Assist Tomogr. 2018;42(5):776-83.

128. Teruel JR, Goa PE, Sjøbakk TE, et al. A simplified approach to measure the effect of the microvasculature in diffusion-weighted MR imaging applied to breast Tumors: preliminary results. Radiology. 2016;281(2):373-81.

129. Teruel JR, Goa PE, Sjøbakk TE, et al. Diffusion weighted imaging for the differentiation of breast tumors: from apparent diffusion coefficient to high order diffusion tensor imaging. J Magn Reson Imaging. 2016;43(5):1111-21.

130. Thakur SB, Durando M, Milans S, et al. Apparent diffusion coefficient in estrogen receptor-positive and lymph node-negative invasive breast cancers at 3.0T DW-MRI: a potential predictor for an oncotype $d x$ test recurrence score. J Magn Reson Imaging. 2018;47(2):401-9.

131. Wan CW, Lee CY, Lui CY, et al. Apparent diffusion coefficient in differentiation between malignant and benign breast masses: does size matter? Clin Radiol. 2016;71(2):170-7.

132. Wang Q, Guo Y, Zhang J, et al. Contribution of IVIM to conventional dynamic contrast-enhanced and diffusion-weighted MRI in differentiating benign from malignant breast masses. Breast Care (Basel). 2016;1 1(4):254-8.

133. Woodhams R, Kakita S, Hata H, et al. Diffusion-weighted imaging of mucinous carcinoma of the breast: evaluation of apparent diffusion coefficient and signal intensity in correlation with histologic findings. AJR Am J Roentgenol. 2009;193(1):260-6.

134. Xie T, Zhao Q, Fu C, et al. Differentiation of triple-negative breast cancer from other subtypes through whole-tumor histogram analysis on multiparametric MR imaging. Eur Radiol. 2019;29(5):2535-44.

135. Yabuuchi H, Soeda H, Matsuo Y, et al. Phyllodes tumor of the breast: correlation between MR findings and histologic grade. Radiology. 2006;241(3):702-9.

136. Yoo H, Shin HJ, Baek S, et al. Diagnostic performance of apparent diffusion coefficient and quantitative kinetic parameters for predicting additional malignancy in patients with newly diagnosed breast cancer. Magn Reson Imaging. 2014;32(7):867-74.

137. Youk JH, Son EJ, Chung J, et al. Triple-negative invasive breast cancer on dynamic contrast-enhanced and diffusion-weighted MR imaging: comparison with other breast cancer subtypes. Eur Radiol. 2012;22(8):1724-34.

138. Zhang M, Horvat JV, Bernard-Davila B, et al. Multiparametric MRI model with dynamic contrast-enhanced and diffusion-weighted imaging enables breast cancer diagnosis with high accuracy. J Magn Reson Imaging. 2019;49(3): 864-74.

139. Zhao J, Guan H, Li M, et al. Significance of the ADC ratio in the differential diagnosis of breast lesions. Acta Radiol. 2016;57(4):422-9.

140. Zhao M, Fu K, Zhang L, et al. Intravoxel incoherent motion magnetic resonance imaging for breast cancer: a comparison with benign lesions and evaluation of heterogeneity in different tumor regions with prognostic factors and molecular classification. Oncol Lett. 2018;16(4):5100-12.

141. Zhou J, Chen $\mathrm{E}, \mathrm{Xu} \mathrm{H}$, et al. Feasibility and diagnostic performance of Voxelwise computed diffusion-weighted imaging in breast Cancer. J Magn Reson Imaging. 2018. https://doi.org/10.1002/jmri.26533.

142. Qu RF, Guo DR, Chang ZX, et al. Differential diagnosis of benign and malignant breast Tumors using apparent diffusion coefficient value 
measured through diffusion-weighted magnetic resonance imaging. J Comput Assist Tomogr. 2015;39(4):513-22.

143. Liu L, Long M, Wang J, et al. Quantitative analysis of diffusion-weighted imaging for diagnosis of puerperal breast abscess after polyacrylamide hydrogel augmentation mammoplasty: compared with other conventional modalities. Aesthet Plast Surg. 2015;39(1):84-90.

144. Guo Y, Kong QC, Zhu YQ, et al. Whole-lesion histogram analysis of the apparent diffusion coefficient: evaluation of the correlation with subtypes of mucinous breast carcinoma. J Magn Reson Imaging. 2018;47(2):391-400.

145. Surov A, Clauser P, Chang YW, et al. Can diffusion-weighted imaging predict tumor grade and expression of $\mathrm{Ki}-67$ in breast cancer? A multicenter analysis. Breast Cancer Res. 2018;20(1):58.

146. Baxter GC, Graves MJ, Gilbert FJ, Patterson AJ. A Meta-analysis of the diagnostic performance of diffusion MRI for breast lesion characterization. Radiology. 2019;291(3):632-41.

\section{Publisher's Note}

Springer Nature remains neutral with regard to jurisdictional claims in published maps and institutional affiliations.

Ready to submit your research? Choose BMC and benefit from:

- fast, convenient online submission

- thorough peer review by experienced researchers in your field

- rapid publication on acceptance

- support for research data, including large and complex data types

- gold Open Access which fosters wider collaboration and increased citations

- maximum visibility for your research: over $100 \mathrm{M}$ website views per year

At BMC, research is always in progress.

Learn more biomedcentral.com/submissions 